\title{
Review \\ ROS-1 Fusions in Non-Small-Cell Lung Cancer: Evidence to Date
}

\author{
Sébastien Gendarme ${ }^{1,2, *}$, Olivier Bylicki ${ }^{3}(0)$ Christos Chouaid ${ }^{1,2}(\mathbb{C})$ and Florian Guisier ${ }^{4,5}(\mathbb{C}$ \\ 1 INSERM, IMRB (Clinical Epidemiology and Ageing Unit), University Paris Est Créteil, F-94010 Créteil, France; \\ christos.chouaid@chicreteil.fr \\ 2 Pneumology Department, Centre Hospitalier Intercommunal de Créteil, 40, Avenue de Verdun, \\ F-94010 Créteil, France \\ 3 Respiratory Disease Unit, HIA Sainte-Anne, 2, Boulevard Saint-Anne, F-83000 Toulon, France; \\ bylicki.olivier@yahoo.fr \\ 4 Department of Pneumology, Rouen University Hospital, 1 Rue de Germont, F-76000 Rouen, France; \\ florian.guisier@chu-rouen.fr \\ 5 Clinical Investigation Center, Rouen University Hospital, CIC INSERM 1404, 1 Rue de Germont, \\ F-76000 Rouen, France \\ * Correspondence: sebastien.gendarme@u-pec.fr
}

Citation: Gendarme, S.; Bylicki, O.;

Chouaid, C.; Guisier, F. ROS-1

Fusions in Non-Small-Cell Lung

Cancer: Evidence to Date. Curr.

Oncol. 2022, 29, 641-658. https://

doi.org/10.3390/curroncol29020057

Received: 25 December 2021

Accepted: 26 January 2022

Published: 28 January 2022

Publisher's Note: MDPI stays neutral with regard to jurisdictional claims in published maps and institutional affiliations.

Copyright: (C) 2022 by the authors. Licensee MDPI, Basel, Switzerland. This article is an open access article distributed under the terms and conditions of the Creative Commons Attribution (CC BY) license (https:// creativecommons.org/licenses/by/ $4.0 /)$.

\begin{abstract}
The ROS-1 gene plays a major role in the oncogenesis of numerous tumors. ROS-1 rearrangement is found in $0.9-2.6 \%$ of non-small-cell lung cancers (NSCLCs), mostly lung adenocarcinomas, with a significantly higher rate of women, non-smokers, and a tendency to a younger age. It has been demonstrated that ROS-1 is a true oncogenic driver, and tyrosine kinase inhibitors (TKIs) targeting ROS-1 can block tumor growth and provide clinical benefit for the patient. Since 2016, crizotinib has been the first-line reference therapy, with two-thirds of the patients' tumors responding and progression-free survival lasting $\sim 20$ months. More recently developed are ROS-1-targeting TKIs that are active against resistance mechanisms appearing under crizotinib and have better brain penetration. This review summarizes current knowledge on ROS-1 rearrangement in NSCLCs, including the mechanisms responsible for ROS-1 oncogenicity, epidemiology of ROS-1-positive tumors, methods for detecting rearrangement, phenotypic, histological, and molecular characteristics, and their therapeutic management. Much of this work is devoted to resistance mechanisms and the development of promising new molecules.
\end{abstract}

Keywords: ROS-1 protein; protein tyrosine-kinase receptors; lung cancers; non-small-cell lung cancer

\section{Introduction}

Lung cancer represents the leading cause of cancer deaths worldwide, with more than 1.8 million deaths in 2020 [1]; 85\% are non-small-cell lung cancers (NSCLCs) and 25\% of them harbor oncogenic alterations that can be targeted by therapy. That is the case for patients whose tumors are positive for proto-oncogene tyrosine-protein kinase-1 (ROS-1; $c$-Ros oncogene-1)-gene fusion. Identification of that translocation makes patients eligible for targeted therapy. Prospective phase I/II trial results have shown the efficacy of crizotinib, that is a tyrosine-kinase inhibitor (TKI) targeting ROS, anaplastic lymphoma kinase protein (ALK) or mesenchymal-to-epithelial transition (MET) protein, and is now recommended as first-line therapy [2-4]. Unfortunately, despite initial responses, ROS-1-positive NSCLCs develop resistances to crizotinib, allowing tumor progression, notably brain metastases. More recently devised new molecules are active against crizotinib resistances and have good brain penetration.

This present review is an update of those previous reviews [5,6] and describes our current knowledge of ROS-1 rearrangement in NSCLCs, including their diagnostic modalities, epidemiology, and characteristics, and the development of diverse molecules targeting ROS-1 and the identified resistance mechanisms. 


\section{ROS-1 Gene}

The ROS-1 gene was discovered in the 1980s as the product of the avian sarcoma virus RNA UR2 (University of Rochester) [7]. This gene codes for 2347 amino acids that form a transmembrane protein sharing structural characteristics with the family of insulin receptors and ALK. The ROS-1 protein is composed of an extracellular domain containing a hydrophobic segment allowing transmembrane passage and an intracellular component containing a tyrosine-kinase domain with a terminal carboxyl [8]. Its physiological role is poorly understood but study results suggest that wild-type ROS is involved during embryonic development as an initiator of signaling events for the differentiation of epithelial tissues [9]. Early during the 2000s, the proto-oncogene role of ROS was first identified in brain tumors. A microdeletion in chromosome $6 \mathrm{q} 21$ is responsible for ROS- 1 fusion with a new fused-in-glioblastoma (FIG) gene that is responsible for ROS-1 overexpression and production of signals abnormally activating the tyrosine-kinase pathway, conferring its proto-oncogene role [10]. In mouse models, FIG-ROS-1 transcript expression induces tumorigenesis and treatment with a small molecule, TAE684, inhibits growth of Baf3 cells overexpressing short and long isoform of FIG-ROS-1, thereby defining ROS-1 as an oncogenic "driver".

The ROS-1 proto-oncogene role in lung cancer was first reported in 2007 by Rikova et al., who identified two other protein fusion transcripts: a transmembrane solute transporter (SLC34A2) and a type-2 transmembrane protein (CD74) [11]. Since then, improved sequencing techniques have enabled the discovery of increasing numbers of fusion partners [12,13], whose proto-oncogene roles in numerous cancers is now clearly established [14].

ROS-1 plays a major role in the activation of several signaling pathways associated with differentiation, proliferation, cell growth, and survival. ROS-1 rearrangement, by forming phosphotyrosine-recruitment sites in the terminal tail of ROS, causes kinase-activity deregulation of the protein and abnormal activation of signaling pathways, mediated by tyrosine-phosphatase tumor-suppressor SHP1/SHP2, pro-mitotic protein extracellular signal-regulated kinase (ERK1/2), insulin-receptor substrate (IRS-1), phosphatidylinositol 3-kinase (PI3K) pathway, protein kinase B (AKT), mitogen-activated protein kinases (MAPKs), signal transducer and activator of transcription (STAT3), and VAV3 [15]. However, the ligand binding to its recruitment site initiating ROS-protein activation remains unknown. Moreover, study results suggest that activation of the pathways could depend on the fusion transcript. Thus, in the case of CD74-ROS-1 fusion, the role played by phosphorylation of the E-Syt-1 (extended synaptotagmin-like) protein could confer the tumor cell with greater metastatic and invasive potential [16].

\section{Epidemiology, Clinical, and Histological Characteristics}

ROS-1 rearrangement is present in approximately $0.9-2.6 \%$ of NSCLCs $[13,17-20]$. Like ALK rearrangements, it is more frequent in young subjects, women and neversmokers [13,17-20]. ROS-1-positive NSCLCs are predominantly lepidic, acinar, or solid adenocarcinomas, with more than 90\% expressing thyroid transcription factor-1 (TTF1), diagnosed at an advanced stage (stage III-IV), with a higher frequency of brain metastases [20-24]. More rarely, ROS-1 rearrangement is found in other histological subtypes, e.g., squamous-cell carcinomas, pleomorphic carcinomas or large-cell carcinomas [13,23,25-27]. Histological examination of these tumors mainly finds a solid architecture with round nuclei containing macronucleolus, "signet-ring cell", and a close relationship with adjacent bronchioles [25]. Imaging shows metastatic lymph-node tropism, often reported with less frequent extrathoracic metastatic sites than for ALK rearranged or epidermal growth factor receptor (EGFR)-mutated NSCLCs [28]. Miliary forms of lung metastases have also been described [29]. Several authors reported a heightened thromboembolic risk of ROS-1-rearranged tumors compared with NSCLCs harboring non-rearranged ROS-1 [30], and even rarer cases of thrombotic microangiopathies [31] and disseminated intravascular coagulation [32]. Although the underlying mechanisms remain to be elucidated, interaction between extracellular carcinoid mucins secreted into the bloodstream and platelet (P-) and 
leukocyte (L-) selectins could trigger platelet activation and the formation of microthrombi responsible for thromboembolic events [33].

\section{Molecular Characteristics}

\subsection{Fusion Partners}

ROS-1 rearrangement occurs at a breakpoint in the ROS gene at the $5^{\prime}$ end of exons $32,34,35$, or 36 , or introns 31 or 33 [14,34]. The most frequently seen fusion partners (Table 1) are CD74 (38-54\%), EZR (13\%-24\%), SDC4 (9-13\%), and SLC34A2 (5-10\%) [34,35]. However, improved DNA- and RNA-sequencing techniques have enabled identification of numerous fusion partners, including CCCKC6, TFG, SLMAP, MYO5C, FIG, LIMA1, CLTC, GOPC, ZZCCHC8, CEP72, MLL3, KDELR2, LRIG3, MSN, MPRIP, WNK1, SLC6A17, TMEM106B, FAM135B, TPM3, and TDP52L1 [36]. The prognostic role of fusion partners is still being debated. The results of several studies showed that the presence of CD74-ROS-1 rearrangement was associated with longer progression-free survival (PFS) and overall survival (OS) than non-CD74-ROS-1 rearrangement [36]. However, that association with survival was not found in other studies [34].

Table 1. Main ROS-1-fusion partners in ROS-1-positive non-small-cell lung cancers.

\begin{tabular}{|c|c|c|c|}
\hline Gene & Description & Frequency & Reference \\
\hline CD74 & Cluster of differentiation 74 (several subtypes: C6R34, C6R32 C7R32, C3R34) & $38-54 \%$ & [11] \\
\hline$E Z R$ & Ezrin & $13-24 \%$ & [37] \\
\hline SDC4 & Syndecan 4 & $9-13 \%$ & [37] \\
\hline SLC34A2 & Solute carrier family-34 member- 2 gene & $5-10 \%$ & [11] \\
\hline TPM3 & Tropomyosin-3 gene & $3-15 \%$ & [14] \\
\hline FIG or GOPC & $\begin{array}{c}\text { Fused in glioblastoma (associated with cancers other than NSCLC) or } \\
\text { golgi-associated PDZ and coiled-coil motif-containing }\end{array}$ & $2-3 \%$ & [38] \\
\hline ADGRG6 & Adhesion G protein-coupled receptor G6 & $1 \%$ & [39] \\
\hline ANKS1B & Ankyrin repeat and sterile alpha motif domain containing $1 \mathrm{~B}$ & $1 \%$ & {$[40]$} \\
\hline CCDC6 or CCKC6 & Coiled-coil domain containing 6 & $1 \%$ & {$[34,41]$} \\
\hline CEP72 & Centrosomic protein 72 & $1 \%$ & {$[42]$} \\
\hline CLTC & Clathrin heavy chain & $1 \%$ & [43] \\
\hline FAM135B & Family with sequence similarity 135 member B & $1 \%$ & [44] \\
\hline FBXF17 & F-box and leucine-rich repeat protein 17 & $1 \%$ & [44] \\
\hline FRK & Src family tyrosine kinase & $1 \%$ & [40] \\
\hline KDELR2, ELP-1 or ERD2.2 & Endoplasmic reticulum protein retention receptor 2 & $1 \%$ & [34] \\
\hline SKT & Human homologue of murine Skt (Sickle tail) & $1 \%$ & [41] \\
\hline LIMA (or EPLIN) & LIM (Lotus-Intel-Microsoft) domain and actin-binding 1 & $1 \%$ & [2] \\
\hline LRIG3 & Leucine-rich repeats and immunoglobulin-like domain 3 & $1 \%$ & [14] \\
\hline MLL3 & Mixed lineage leukemia & $1 \%$ & [12] \\
\hline MPRIP & Myosin phosphatase Rho-interacting protein & $1 \%$ & [45] \\
\hline MSN & Moesin & $1 \%$ & [2] \\
\hline MYH9 & Myosin, heavy polypeptide 9 , non-muscle & $1 \%$ & {$[34,46]$} \\
\hline MYOC 5 & Myosin-gene family myosin VC & $1 \%$ & [23] \\
\hline RBPMS & RNA-binding protein with multiple splicing & $1 \%$ & [47] \\
\hline$S L C 2 A 4 R G$ & solute carrier family- 2 member- 4 & $1 \%$ & [34] \\
\hline SLC6A17 & Solute carrier family- 6 member- 17 & $1 \%$ & [42] \\
\hline SLMAP & Sarcolemma-associated protein & $1 \%$ & [23] \\
\hline SNN & Stannin & $1 \%$ & [41] \\
\hline SQSTM1 & Sequestosome 1 & $1 \%$ & [40] \\
\hline TDP52L1 & Tumor protein D52-like 1 & $1 \%$ & [42] \\
\hline TMEM106B & Transmembrane protein 106B & $1 \%$ & [8] \\
\hline TRG or TFG & TRK (transketolase-related gene)-fused gene & $1 \%$ & [41] \\
\hline WNK1 & Lysine deficient protein kinase 1 & $1 \%$ & {$[34,41]$} \\
\hline $\mathrm{ZZCCHC8}$ or $\mathrm{ZCCH}$ & Zinc finger $\mathrm{CCHC}$-type containing 8 & $1 \%$ & {$[41]$} \\
\hline
\end{tabular}

\subsection{Oncogenic Co-Mutations}

About 36\% of ROS-1-positive NSCLCs have oncogenic co-mutations [48]. Their frequencies are lower compared to cancers with non-rearranged ROS-1 [35] and are usually mutually exclusive with Kirsten rat-sarcoma viral oncogene (KRAS), EGFR, and ALK mutations [49]. However, rare co-mutations with other so-called driver oncogenes have been reported [50,51]. Lambros et al., reported 15 cases of co-mutations between ROS-1 and EGFR with nine exon-19 deletions, one exon-20 insertion, and five L858R mutations. A first-line EGFR TKI obtained a tumor response or stability for $80 \%$ of the patients. ROS-1 rearrangement appeared in one tumor as a resistance mechanism under EGFR-TKI and crizotinib was able to obtain a partial response [52]. A low percentage of co-mutations involving EGFR was reported in several papers [48]. Extremely rare ALK and ROS-1 
co-mutations have also been described [50,53]. Given that both of these mutations are sensitive to crizotinib, the treatment choice is less problematic than for other co-mutations. The NSCLCs of all reported patients who had benefited from systemic treatment responded to crizotinib.

KRAS co-mutations can be present at diagnosis or progression. The scarce data available in this setting render evaluation of crizotinib sensitivity difficult. Based on six patients with KRAS-ROS co-mutation at diagnosis, a tumor response was obtained for 1; but not in KRASG13D- or G12V-mutation carriers [48,49].

ROS-1-positive NSCLCs with MET amplification are extremely rare. Tang et al., explored the genetic co-alterations involving ALK, ROS-1, RET, and MET in a series of 15 patients and found one ROS-1-MET co-mutation but they provided no treatment information [54]. One reported case of ROS-1-c-MET co-mutations experienced capmatinib (TKI anti-MET) failure followed by a 11 months crizotinib benefit [55]. In contrast, Zeng et al., described a patient with ROS-1-positive NSCLC and MET amplification whose tumor progressed 1.5 months after starting crizotinib [56].

Co-mutations between ROS-1-BRAF (v-RAF murine sarcoma viral oncogene homolog B) have been published, but without any information on anti-ROS-1 or anti-BRAF treatments in this context [24,48]. To the best of our knowledge, ROS-1 co-mutation with rearranged-during-transfection translocation $(R E T)$ or human epidermal growth factor receptor 2 (HER2) have not been described to date. Other non-targetable co-mutations also have a prognostic role, for example, tumor protein 53 (TP53), which was associated with shorter survival in one study [57]. In another study, Zeng et al. [56] found that patients whose NSCLCs had an exclusive ROS-1 fusion lived longer without progression than those whose tumors carried a ROS-1 fusion with co-mutations (15.5 vs. 8.5 months, respectively; $p=0.0213)$.

\section{Techniques of ROS-1 Detection}

It is now recommended that ROS-1 rearrangement be sought in all metastatic lung carcinomas, regardless of clinical characteristics. This search should also be considered in tumors with mixed histologies, when an adenocarcinoma component cannot be excluded.

For metastatic squamous-cell tumors, ROS-1 status can be assessed for never-smokers [57]. Immunohistochemistry (IHC) is used as a screening technique but positive or questionable results require confirmation by fluorescence in situ hybridization (FISH) or next-generation sequencing (NGS) [57]. Running NGS at diagnosis is also an alternative [58].

IHC ROS-1-labeling is located in the cytoplasm but can vary depending on the fusion partner [59]. Three commercialized anti-ROS-1 antibodies are available: clone D4D6 (Cell Signaling Technology, Danvers, MA, USA), which is used in clinical studies; clone SP384 (Roche, Ventana, AZ, USA); and clone 1A1 (Origene, Rockville, MD, USA) [60]. All those clones have high sensitivity (90-100\%), compared to FISH and NGS. However, unlike ALK IHC, ROS-1 specificity is variable, ranging from $70 \%$ to $90 \%$ [61], and depends on the clone used [62] and the positivity threshold applied [63,64]. Thus, almost a third of the patients with IHC-positive tumors do not have ROS-1 rearrangement $[48,65]$. The IHC falsepositives are more frequent for lepidic and/or acinar EGFR-mutated adenocarcinomas [66]. Hence, it is now recommended that IHC-positivity and questionable ROS-1 results be confirmed with another technique: FISH, reverse transcription quantitative polymerase chain reaction (RT-qPCR) or NGS.

FISH is the gold standard to diagnose ROS- 1 rearrangements, using a dual probe $\left(3^{\prime}\right.$ and $5^{\prime}$ ) break-apart design. The sample is considered positive when more than $15 \%$ of the cells show separation of both $3^{\prime}$ and $5^{\prime}$ probes or a unique $3^{\prime}$ signal (centromeric) [65]. More than 50 tumor cells must be present to validate a positive finding. This technique has a relatively high price tag, technical difficulties (sufficient amount of tumor cells), and is operator-time consuming. At present, probes able to search simultaneously for $A L K$ and ROS-1 rearrangements, such as Vysis ALK/ROS-1 Dual Break Apart Probe Kit (RUO)) or FlexISH ALK/ROS-1 DistinguISH Probe Zytvision, require less tumor material and can be 
run on cytological samples $[67,68]$. IHC and FISH correspondence is high, but discordance between IHC and FISH is possible [69].

Notably, two situations can have major clinical consequences: (1) positive IHC-labeling of ROS-1 and negative FISH attributable to the presence of another oncogenic driver mutation, whose diagnosis is rectified by RT-PCR or NGS [70]; or (2) a false-negative FISH for certain fusion partners, primarily GOPC-ROS-1 or EZR-ROS-1 [71]. In the latter fusion, deletion of the $5^{\prime}$ end of ROS- 1 and unique $3^{\prime}$-probe-binding in FISH are often found [72]. Pertinently, authors of a recent study comparing IHC of ROS-1 clone SP384 to NGS also described IHC-positive expression in NSCLCs with rare ROS-1 fusions (SQSTM1), ROS-1 mutations and ROS-1 amplifications [38]. Thus, when a minor doubt persists after IHC and FISH, NGS should be run.

RT-qPCR uses primers specific to ROS-1 fusion to confirm the presence of ROS-1 rearrangement. However, the technique is not easily mastered, requiring different steps including RNA extraction, complementary DNA (cDNA) synthesis, quantitative PCR and analysis, which are all sources of variation [73]. This test's performance is excellent, with $100 \%$ sensitivity and $85.1 \%$ specificity, according to one study [74].

NGS is able to identify all fusion partners, including new variants, and other oncogenic molecular alterations potentially targetable, by using tumor DNA or RNA [75]. Although DNA-based sequencing is able to detect rearrangements of fusion genes in intron regions, those genes often differ from messenger RNA (mRNA) fusions [76]. NGS can be run on tumor tissue or plasma [12]. However, its cost and time to results limit its use in routine clinical practice.

\section{Treatment of ROS-1-Positive NSCLCs}

Two TKIs have been validated as first-line therapy for ROS-1-positive NSCLCs: crizotinib, approved in 2016 by the Food Drug Administration (FDA) and the European Medications Agency (EMA), and entrectinib approved by the FDA in 2019 and EMA in 2020 [3,4].

\subsection{Crizotinib}

The results of the phase I PROFILE 1001 trial (NCT00585195), conducted on about 50 patients with metastatic ROS-1-positive NSCLCs, demonstrated crizotinib efficacy [2]. Given at a dose of $250 \mathrm{mg}$ twice daily [2,77], the objective response rate (ORR) was $72 \%$ (95\% CI 58-83\%), the disease-control rate (DCR) was $90 \%$, with median duration of response (DOR) at 24.7 (95\% CI 15.2-45.3) months, and median PFS and OS, respectively, at 19.3 (95\% CI 15.2-45.3) and 51.4 (95\% CI 29.3-not reached) months. The most frequent adverse events were: vision disturbances ( $82 \%)$, diarrhea $(44 \%)$, nausea $(40 \%)$, peripheral edema $(40 \%)$, constipation $(34 \%)$, vomiting $(34 \%)$, elevated transaminases $(22 \%)$, fatigue $(20 \%)$, and dysgeusia $(18 \%)$, mainly grade 1 or 2 . Toxicity never required crizotinib withdrawal.

Retrospective trials $[78,79]$ and then prospective phase II trials $[46,80-82]$ confirmed crizotinib efficacy in this population (Table 2). The phase III AcSé study, based on 37 patients, found an ORR of $47.2 \%$ [95\% CI 30.4-64.5], with median PFS and OS, respectively, at 5.5 [95\% CI 4.2-9.1], and 17.2 [95\% CI 6.8-32.8] months. Those findings were less favorable than those of the PROFILE 1001 trial, probably because of a higher percentage of patients with Eastern Cooperative Oncology Group performance score (PS) $=2(25 \%$ vs. $2 \%)$, who had been more heavily pre-treated [82]. The results of the European EUCROSS and METROS studies were closer to those obtained in the PROFILE 1001 trial, with respective ORRs of 70\% [95\% CI 51-85] and 65\% [95\% CI 44-82], with median PFS at 20 [95\% CI 8.3-not reached], and 22.8 [95\% CI 15.2-30.3] months. Factors associated with a poor prognosis were the presence of brain metastases, more than two metastatic sites and a TP53 mutation $[41,46,81,82]$. The presence of a CD74-ROS- 1 fusion was associated with a more favorable prognosis in some studies [41] but had no impact according to others $[36,83,84]$. 
Table 2. Summary of clinical trials on tyrosine-kinase inhibitors (TKIs) targeting ROS-1 in patients with ROS-1-positive non-small-cell lung cancers.

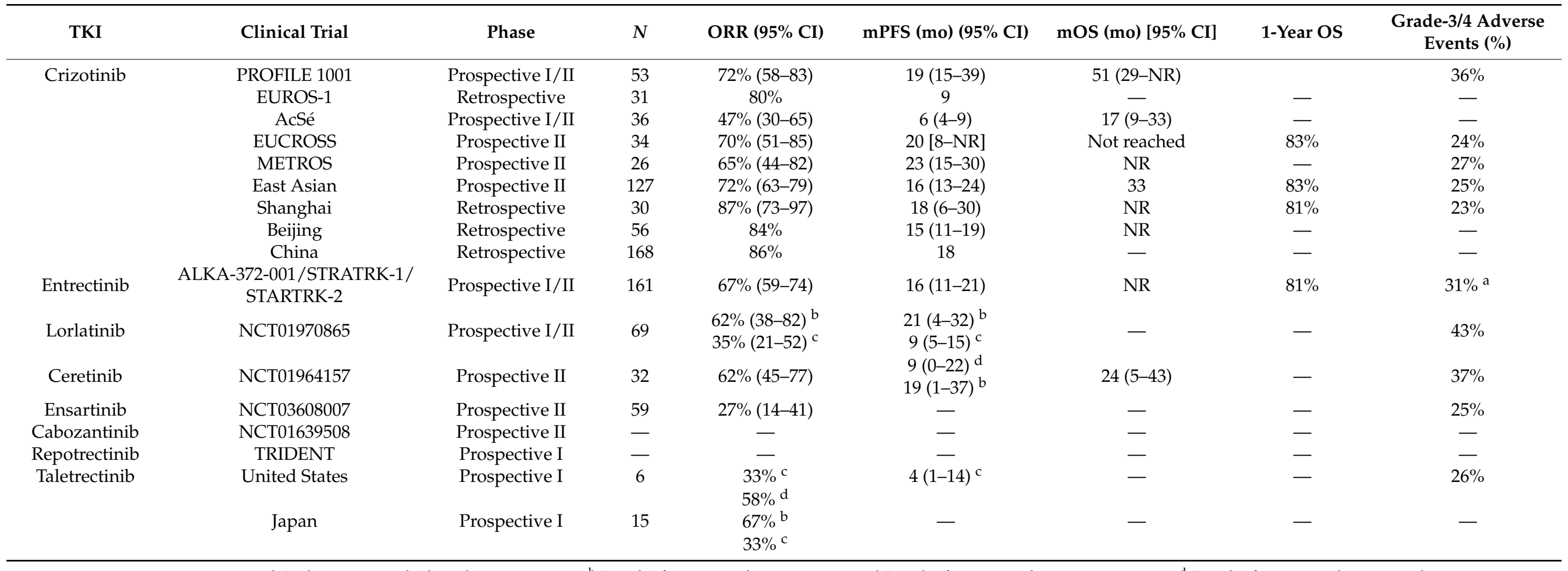

a Preliminary results based on 53 patients, ${ }^{b}$ Results for crizotinib-naïve patients, ${ }^{c}$ Results for crizotinib-resistant patients, ${ }^{d}$ Results for crizotinib-naïve and -resistant patients. Abbreviations: $\mathrm{ORR}=$ objective response rate; $\mathrm{mPFS}=$ median progression-free survival; $\mathrm{mOS}=$ median overall survival; $\mathrm{CI}=$ confidence interval; $\mathrm{NR}=$ not reached. 
Despite crizotinib's notable benefit in the management of ROS-1-positive NSCLCs, its poor brain penetration makes the central nervous system the primary site of progression under crizotinib (47\% of patients). Moreover, given that $36 \%$ of patients with ROS-1-positive NSCLCs have brain metastases at diagnosis [22], the development of new ROS-1-targeting molecules with better cerebral penetration, such as entrectinib or lorlatinib, is justified.

\subsection{Entrectinib}

Entrectinib, a multikinase inhibitor targeting ROS-1, ALK or pan-tropomyosin-receptor kinase (TRK), penetrates the blood-brain barrier [85]. In vitro, its anti-ROS-1 activity is $40 \times$ more potent than that of crizotinib [86]. Two phase I/II trials showed entrectinib's anti-tumoral activity and its good tolerance profile (Table 2) [87]. Its most frequent adverse events were: dysgeusia (41.4\%), fatigue (27.9\%), vertigo (25.4\%), constipation (23.7\%), diarrhea $(22.8 \%)$, nausea $(20.8 \%)$, and weight gain $(19.4 \%)$. The results of the phase II basket study (STARTRK-2) confirmed entrectinib efficacy in 161 anti-ROS-1 treatmentnaïve patients with ROS-1-positive NSCLCs, among whom 34.8\% had brain metastases at diagnosis [88,89]. An updated analysis of the entire population found: ORR $=67.1 \%$ [95\% CI 59.3-4.3], median PFS = 15.7 [95\% CI 11.0-21.1] months, and median 1-year OS at 81\% [95\% CI 74-87]. For the 24 patients with measurable brain metastases at diagnosis, centralized assessment of the brain outcomes found ORR $=79.2 \%$ [95\% CI 57.9-92.9], with median PFS at 12 months. The reported outcomes of 145 patients indicated nonclinically significant improvement of physical-function scores and quality of life (QOL; Health-Related Quality of Life scale) [90].

Based on those findings, entrectinib was approved in August 2019 by the FDA and the EMA accorded temporary authorization utilization in August 2020 to treat adults and children over 12 years old with ROS-1-rearranged NSCLCs at a dose of $600 \mathrm{mg} /$ day [91].

\subsection{Lorlatinib}

Lorlatinib, a TKI active against ALK and ROS-1, was specifically developed to penetrate the blood-brain barrier by reducing the efflux mediated by P-glycoprotein-1. Lorlatinib (100 mg once daily) anti-tumor activity against ROS-1-positive NSCLCs was demonstrated in a phase I trial followed by a phase I/II trial on 61 TKI treatment-naïve $(n=21)$ or crizotinib-treated $(n=40)$ patients given another TKI $(n=8)$ (Table 2) [92-94]. TKI treatmentnaïve patients obtained an ORR of $62 \%$ [95\% CI 38-82], median PFS of 21 [95\% CI 4.2-31.9] months and brain ORR of $64 \%$ [95\% CI 31-89]. Median brain PFS was not reached, further supporting this molecule's good efficacy against these metastases. For the crizotinib-pretreated patients, ORR, median PFS and intracerebral objective response rate, respectively, were: 35\% [95\% CI 21-52], 8.5 [95\% CI 4.7-15.2] months, and 50\% [95\% CI 29-71]. Grade-3 or -4 adverse events occurred, respectively, in $43 \%$ and $6 \%$ of the patients, with the most frequent being hypercholesterolemia (65\%), hypertriglyceridemia (42\%), peripheral edema $(39 \%)$, peripheral neuropathies, (35\%), altered cognitive functions $(26 \%)$, weight gain $(16 \%)$, and mood disorders (16\%). Monitoring of plasma lorlatinib concentrations might achieve better control of adverse events without modifying anti-tumor efficacy [95]. Lorlatinib also achieved improved QLQ-C30 scale-evaluated QOL [96]. Lorlatinib efficacy seems to be even better when an ROS-1 ${ }^{\mathrm{K} 1991 \mathrm{E}}$ or ROS-1 ${ }^{\mathrm{S} 1986 \mathrm{~F}}$ mutation is the mechanism of resistance against crizotinib; however, despite promising in vitro findings, activity appears to be more limited against the ROS-1 G2032R mutation, the principal resistance mechanism of ROS-1positive NSCLC under crizotinib [97]. Notably, the NSCLCs of six patients harboring the ROS-1 ${ }^{\mathrm{G} 2032 \mathrm{R}}$ mutation did not respond to lorlatinib in the phase I/II trial [94]. In addition, the tumor responses to lorlatinib after failure on entrectinib were also reported [98] but on too few patients to be meaningful. These exploratory observations must be confirmed to better specify the place of lorlatinib according to the tumor's resistance profile to crizotinib. 


\subsection{Ceritinib}

Ceritinib, a powerful ALK-specific inhibitor, exhibited antitumor efficacy and brain activity in patients with ALK-rearranged NSCLCs that progressed under crizotinib [99]. In vitro findings also suggested potent ceritinib inhibitory activity against ROS-1 [100]. A phase II study on 32 patients with ROS-1-positive NSCLCs, predominantly crizotinibnaïve $(n=30)$, treated with ceritinib (750 daily) achieved an ORR of $62 \%$ [95\% CI 45-77], with median PFS $=9.3$ [95\% CI 0-22] months [100] (Table 2). In the subgroup of crizotinibnaïve patients, PFS lasted 19.3 [95\% CI 1-37] months, comparable to those of other TKIs (entrectinib, lorlatinib). For the eight patients with brain metastases, the brain ORR was $63 \%$ [95\% CI 31-86\%]. Its tolerance profile was similar to those of other molecules, with $37 \%$ grade- 3 adverse events. Those results do not make ceritinib a challenger for first-line crizotinib but it could have its place as a subsequent-line agent, according to the resistance profile and the progression sites.

\subsection{Cabozantinib}

Cabozantinib, a small molecule TKI, selectively targets MET, VEGFR-2, RET, ROS-1, and AXL, with good brain penetration. Pre-clinical and case-report findings suggest that cabozantinib can be effective in patients with NSCLCs resistant to other TKIs (crizotinib, entrectinib, ceritinib) by binding to ROS-1, despite the presence of resistance mutations, such as D2033N or G2032R [100,101]. Hence, cabozantinib could be a clinically pertinent agent to overcome crizotinib-resistance of ROS-1-positive NSCLCs [102]. An ongoing phase II trial (NCT01639508) is evaluating cabozantinib efficacy for this indication, with results expected in July 2022.

\subsection{Brigatinib}

Brigatinib, another ROS-1 inhibitor, has demonstrated anti-tumor activity against several crizotinib-resistance mechanisms [103]. One study assessed brigatinib efficacy and tolerance on eight patients ROS-1-positive NSCLCs, among whom 1 was TKI treatmentnaïve and seven progressed post-crizotinib [104]. Their overall ORR to brigatinib was $37 \%$ and $29 \%$ for the seven post-crizotinib progressors. No grade- 3 or -4 adverse event was reported. According to a case report, a tumor response was observed in a patient who had received several lines of anti-ROS-1 TKIs [105]. In vitro anti-tumor activity was suggested for NSCLC carrying the L2026M mutation [106] but no brigatinib efficacy against the G2032R mutation was found [103].

\subsection{Other TKIs}

In analogy to driver mutations, the current challenge of managing ROS-1-positive NSCLCs is the development of molecules with good brain penetration and activity against the main resistance mechanisms emerging under TKI(s). The ROS- ${ }^{\mathrm{G} 2032 \mathrm{R}}$ resistance mutation is now the main target of new agents being developed.

Repotrectinib (TPX-0005) is a next-generation TKI that can target ROS-1, TRK, or ALK. Its properties enable its passage through the blood-brain barrier. This molecule was evaluated in pre-clinical models based on patients with ROS-1-positive NSCLCs [107]. The encouraging modeling results showed anti-tumor activity against brain ROS-1-positive metastases, treatment- ROS-1-positive, ROS-1-positive ceritinib-resistant, and ROS-1 ${ }^{\mathrm{G} 2032 \mathrm{R}}$ NSCLCs. A clinical phase I/II trial (NCT03093116) is ongoing, with results expected in December 2022.

Taletrectinib (DS-6051B), a selective inhibitor of ROS-1 and neurotrophic TRAK (NTRAK), is capable of inhibiting crizotinib-resistant ROS-1-rearranged NSCLCs, including those harboring the G2032R mutation. Pre-clinical study results showed its efficacy in different mouse models derived from patients with ROS-1-positive NSCLCs [108]. Its in vitro activity against G2032R, L1951R, S1986F and L2026M mutations make it a particularly interesting molecule. In contrast, its activity is less certain against the D2033N mutation, for which it has higher minimal inhibitory concentrations (MICs). The clinical efficacy of this agent is 
being evaluated in two phase I trials, one American (U101, NCT02279433) and the other Japanese (Table 2) [109]. The former enrolled 46 patients and found 33\% ORR for those with crizotinib-resistant tumors; the latter, conducted on 15 patients, reported $58.3 \%$ ORR for all patients and $66.7 \%$ for those crizotinib-naïve [109]. Brain activity was also observed but remains to be demonstrated. Thus, should efficacy and tolerance be confirmed, taletrectinib could play a promising role in the management of ROS-1-positive NSCLCs, notably those crizotinib-resistant.

Ensartinib (X-396) is a TKI with in vitro activity 10-fold higher than that of crizotinib against ALK [110]. Results of a recent phase II trial on ROS-1-positive NSCLCs (NCT03608007) showed modest efficacy of this molecule (ORR 27\%, 95\% CI 13.8-44.1) but interesting brain disease control in three out of four patients [111]. However, at present, use of this product in the management of NSCLCs harboring ROS-1-fusion genes has been retrograded.

\subsection{What Is the Place of other Anti-Cancer Therapies?}

Chemotherapy remains the reference second-line treatment after failure on crizotinib. Pemetrexed-based chemotherapy has potentially notable benefit against ROS-1-positive NSCLCs [112]. Anti-angiogenic agents could also play a role in combination with a TKI. Combining vascular endothelial growth factor (VEGF)-pathway blockade with a TKI targeting ROS-1 in vitro improved the anti-tumor effect compared to TKI alone [113]. According to a study based on 14 patients, the crizotinib-bevacizumab combination achieved efficacy against ALK-positive, ROS-1-positive or MET-amplified tumors with 58.3\% ORR and an acceptable tolerance profile. Three patients developed hepatic toxicity or hemoptysis that required treatment discontinuation. Other TKI-anti-angiogenic agent combinations also yielded results of interest. Clinical trials on different combinations, such as BOOSTER (osimertinib-bevacizumab), could provide some answers about the potential benefits of this combined therapy [114].

The benefit of immunotherapy for ROS-1-positive NSCLCs, notably against crizotinibresistant tumors, is unclear. In vitro and mouse models demonstrated that ROS-1 plays a role and modulates programmed death protein ligand-1 (PD-L1) expression via activation of MEK-ERK- and ROS-1-SHP2-signaling pathways [115]. In clinical practice, most ROS-1positive tumors do not express PD-L1 and have a low mutation burden [115]. However, concerning other mutation drivers such as ALK or EGFR that apparently do not benefit from immunotherapy, the ORR for ROS-1-positive NSCLCs under the latter was 13-17\% [116] and reached $83 \%$ in combination with chemotherapy but on small sample sizes [117]. Choudhury et al. [115] found no PD-L1-expression difference between responders and non-responders. Immunotherapy could also find a place in the therapeutic sequence for tumors resistant to several TKI lines combined with chemotherapy. Special attention should be paid to the toxicity risk of sequential immunotherapy-TKI treatments [115].

\section{ROS-1-Positive NSCLC Resistance Mechanisms}

\subsection{Under Crizotinib}

Crizotinib treatment of ROS-1-positive NSCLCs controls the disease for a median duration of 19 months before the tumor develops crizotinib-resistance mechanisms and tumor progression is observed. These resistance mechanisms are multiple: (1) appearance of a punctual mutation in the ROS-1-kinase domain and induces a modification of the binding site; (2) activation of other signaling pathways; and (3) phenotypic changes (mesenchymalto-epithelial transition, transformation into small cells) $[118,119]$.

\subsubsection{Punctual Mutation in the Kinase-Binding Domain (40-55\%)}

ROS-1-kinase-domain modification is the crizotinib-resistance mechanism (Table 3). First reported in 2013 [120], the G2032R mutation is the most frequent and represents $33 \%-41 \%$ of resistance mechanisms; it occurs in the solvent-front region of the ATPbinding site [120]. In in vitro studies, ROS $^{\mathrm{G} 2032 \mathrm{R}}$ increased TWIST1 expression and led to 
mesenchymal-to-epithelial transition of cells and cell migration [121,122]. It induced resistance to several TKIs (crizotinib, ceritinib, entrectinib, and lorlatinib) via modification of the binding site and steric hindrance. At present, new-generation TKIs are being developed to target that mutation, with promising results obtained with repotrectinib and topotrectinib. Cabozantinib and foretinib have also shown anti-ROS ${ }^{\mathrm{G} 2032 \mathrm{R}}$ activity [102].

Table 3. Sensitivities of resistance mutations appearing in the ROS-1 kinase domain to the different tyrosine-kinase inhibitors. (red: No anti-tumor activity (in vitro and/or clinical); orange: In vitro anti-tumor activity only at high concentration; green: Anti-tumor activity (in vitro and/or clinical) demonstrated).

\section{Resistance Mutation in the ROS-1 Kinase Domain}

U

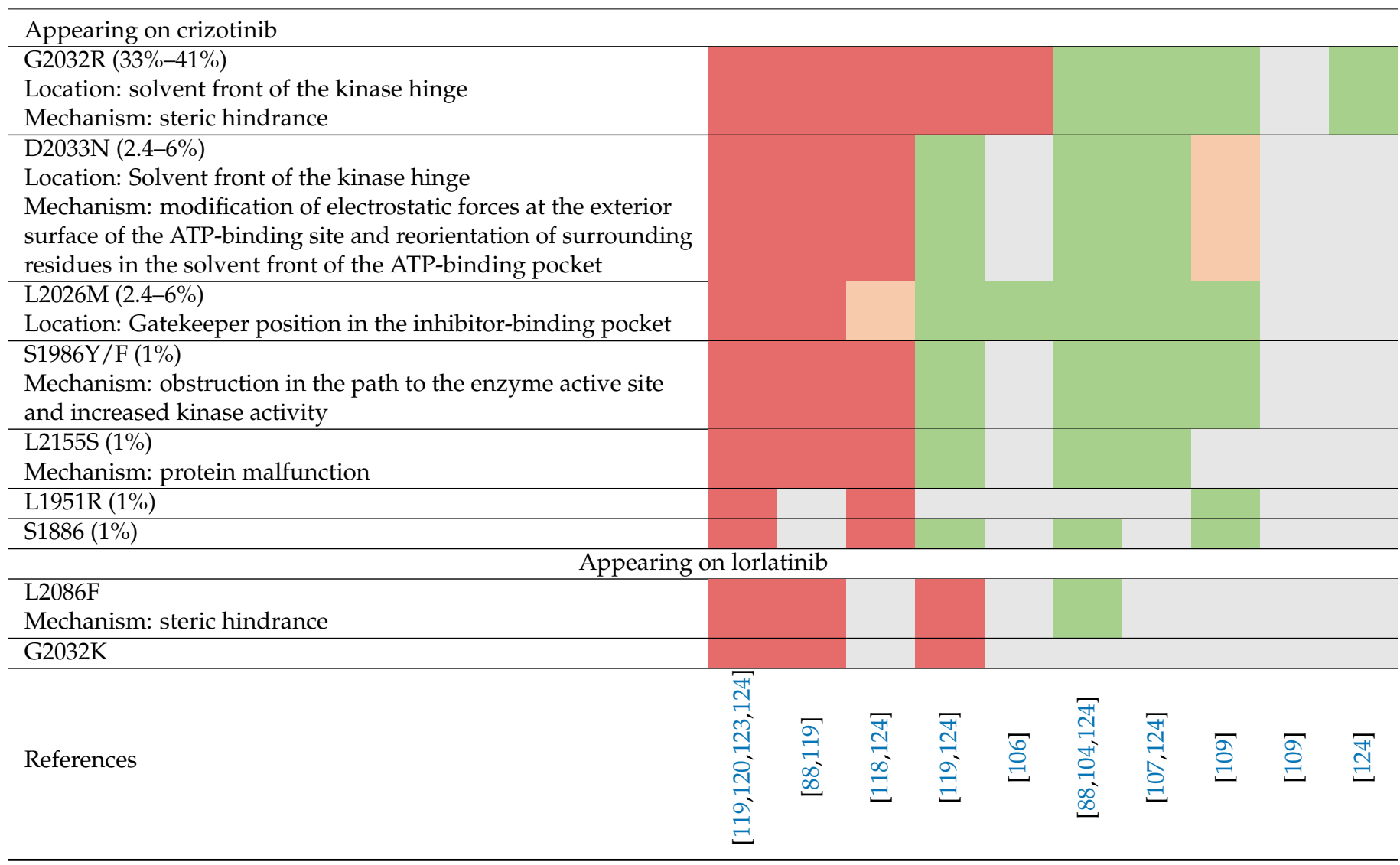

Other frequent mutations, in order of decreasing rates, are: D2033N (2.4-6\%), S1986Y /F (2.4-6\%), L2026M (1\%), L2155S (1\%), L1951R (1\%), and S1886 (1\%) [102]. ROS ${ }^{\mathrm{D} 2033 \mathrm{~N}}$ induces a modification in the ATP-binding-site pocket and modified electrostatic interactions necessary for binding to anti-ROS-1 TKIs. In vitro, that mutation led to resistance to crizotinib, entrectinib, and ceritinib, while lorlatinib, repotrectinib, and cabozantinib remained sensitive. ROS-1 ${ }^{\mathrm{S} 1986 \mathrm{~F}}$ confers resistance to crizotinib, entrectinib and ceritinib by changing the position of the glycine-rich loop at the $\alpha \mathrm{C}$ helix end [123]. The resistance profiles of other mutations are given in Table 3.

\subsubsection{Activation of Other Signaling Pathways}

Crizotinib-resistance can also be linked to activation of other signaling pathways located after the ROS-1-protein kinase. Activation of these mechanisms can engender: 
(1) ROS-1 stimulation of signaling pathways resistant to inhibition by TKIs; (2) acquisition of new mutations or amplifications at the level of other proto-oncogene pathways. In the former case, SHP2 activation of the mitogen-activated protein kinase (MAPK) MEK/ERK pathway conferred TKI-resistance. In vitro, concomitant administration of SHP2 and TKI inhibitors better inhibited tumor growth and constitutes a promising avenue of research [125]. Activation of other signaling pathways, such as KIT, PI3K, and EGFR, has also been reported [34]. In the second case, mutations of ALK [125], BRAF [126], KRAS, neuroblastoma rat-sarcoma viral oncogene (NRAS) [34], and MET [127] genes and MET amplifications [128] have been described. A BRAFV600E mutation was found in two patients [78]; treatment with dabrafenib and trametinib was started, but both died shortly after starting therapy. For the MET mutation, tumor control was short-lived under cabozantinib [78]. For MET amplification, the patient died before having received an anti-MET-specific agent [127].

\subsubsection{Phenotype Change}

Phenotype transformation into a small-cell carcinoma was described as a ROS-1 resistance mechanism in a case report [129]. Based on autopsy findings, this phenotype change was associated with retinoblastoma-1 (RB1)- and TP53-gene inactivations, and loss of ROS-1-fusion expression [130]. This resistance mechanism is well-described with other oncogenic drivers, such as EGFR mutations or ALK rearrangements [131]. "Secondary" small-cell carcinomas with driver mutations seem less sensitive to platinum-etoposide chemotherapy than "primary" small-cell carcinomas. In the case of secondary ROS-1 rearrangement, the patient's tumor responded only to platinum-etoposide chemotherapy. Optimal therapeutic management of histological transformation remains to be determined.

\subsection{Under Lorlatinib}

ROS-1 resistance mechanisms appearing under TKIs other than crizotinib have not been thoroughly examined. Lin et al., analyzed 28 biopsies of ROS-1-positive tumors that had progressed under lorlatinib. Other punctual mutations in the kinase domain were reported, notably G2032K and L2086F mutations (Table 3) [119]. Resistance to crizotinib, entrectinib and lorlatinib was shown in vitro for the ROS-1 ${ }^{\text {G2032K }}$ variant. For the ROS$1^{\mathrm{L} 2086 \mathrm{~F}}$ variant, structural models to predict resistance to crizotinib, entrectinib and lorlatinib suggested potential cabozantinib efficacy [119]. One patient with an L2086G mutation received cabozantinib that controlled the disease for 11 months. Other lorlatinib-resistance mechanisms were also identified, including MET amplification (4\%), KRAS ${ }^{\mathrm{G} 12 \mathrm{C}}$ mutation (4\%), KRAS amplifications (4\%), NRAS amplifications (4\%), and MAP2K1 mutations (4\%). In a phase I trial on taletrectinib, an L2086F resistance mutation was also found in a patient whose tumor was sensitive to cabozantinib [109].

\section{What Strategy for the Therapeutic Management of ROS-1-Positive NSCLCs?}

Despite the development of new molecules with highly promising pre-clinical phase anti-ROS-1 activity, none has yet demonstrated superiority over crizotinib, which remains the first-line reference therapy for metastatic ROS-1-positive NSCLCs [132]. When brain metastases are found, entrectinib is a therapeutic option for crizotinib-naïve patients. At present, the appearance of resistance mechanisms and activation of escape pathways inevitably lead to tumor progression, with a median time to progression of 5.5-20 months, depending on the patient's characteristics. When NSCLCs progress on crizotinib, the choice of second-line therapy depends on the type of progression and the molecular profile of the resistant tumor. In the case of oligo-progression, stereotaxic radiotherapy delivered to the progression site should be considered, notably for a brain location [132,133]. For diffuse progression, platinum-doublet-based chemotherapy remains the standard. Some authors prescribed second-line therapy adapted to the resistance mechanism: lorlatinib for non-G2032R mutations and platinum-doublet-based chemotherapy for the G2032R mutation [133]. 


\section{Conclusions}

Targeted therapies are the cornerstone to treat metastatic ROS-1-positive NSCLCs. Crizotinib remains the first-line reference therapy but new molecules, better able to penetrate the blood-brain barrier, such as entrectinib or lorlatinib, have a role to play in the control of brain disease. However, as for other oncogenic drivers, better understanding of the resistance mechanisms is now essential to guide the choice of the optimal therapeutic sequence. New molecules, such as repotrectinib or taletrectinib, are promising, especially to counter the ROS-1-G2302R-fusion variant, the predominant resistance mechanism under crizotinib.

The small number of patients in this specific category make devising randomized clinical trials impossible, but orienting patients towards such endeavors remains important for the development or therapies adapted to the molecular profile of each patient.

Author Contributions: S.G. researched data for article, substantially contributed to discussion of content, wrote the article, and reviewed/edited the manuscript before submission. O.B., C.C. and F.G. substantially contributed to discussion of content and reviewed/edited the manuscript before submission. All authors have read and agreed to the published version of the manuscript.

Funding: This research received no external funding.

Institutional Review Board Statement: Not applicable.

Informed Consent Statement: Not applicable.

Data Availability Statement: Not applicable.

Conflicts of Interest: The authors declare no conflict of interest.

\section{References}

1. World Health Association. WHO Fact Sheet on Cancer. Available online: https://www.who.int/news-room/fact-sheets/detail/ cancer (accessed on 20 October 2018).

2. Shaw, A.T.; Ou, S.-H.I.; Bang, Y.-J.; Camidge, D.R.; Solomon, B.J.; Salgia, R.; Riely, G.J.; Varella-Garcia, M.; Shapiro, G.I.; Costa, D.B.; et al. Crizotinib in ROS1-Rearranged Non-Small-Cell Lung Cancer. N. Engl. J. Med. 2014, 371, 1963-1971. [CrossRef] [PubMed]

3. U.S. Food and Drug Administration. FDA Approves Crizotinib Capsules. Available online: https://www.fda.gov/drugs/ resourcesi-nformation-approved-drugs/fda-approves-crizotinib-capsules (accessed on 17 November 2021).

4. European Medicines Agency. Xalkori, INN-Crizotinib. Available online: https://www.ema.europa.eu/en/documents/productinformation/xalkori-epar-product-information_en.pdf (accessed on 17 November 2021).

5. D’Angelo, A.; Sobhani, N.; Chapman, R.; Bagby, S.; Bortoletti, C.; Traversini, M.; Ferrari, K.; Voltolini, L.; Darlow, J.; Roviello, G. Focus on ROS1-Positive Non-Small Cell Lung Cancer (NSCLC): Crizotinib, Resistance Mechanisms and the Newer Generation of Targeted Therapies. Cancers 2020, 12, 3293. [CrossRef] [PubMed]

6. Guaitoli, G.; Bertolini, F.; Bettelli, S.; Manfredini, S.; Maur, M.; Trudu, L.; Aramini, B.; Masciale, V.; Grisendi, G.; Dominici, M.; et al. Deepening the Knowledge of ROS1 Rear-rangements in Non-Small Cell Lung Cancer: Diagnosis, Treatment, Resistance and Concomitant Alterations. Int. J. Mol. Sci. 2021, 22, 12867. [CrossRef] [PubMed]

7. Balduzzi, P.C.; Notter, M.F.; Morgan, H.R.; Shibuya, M. Some biological properties of two new avian sarcoma viruses. J. Virol. 1981, 40, 268-275. [CrossRef]

8. Roskoski, R. ROS1 protein-tyrosine kinase inhibitors in the treatment of ROS1 fusion protein-driven non-small cell lung cancers. Pharmacol. Res. 2017, 121, 202-212. [CrossRef] [PubMed]

9. Acquaviva, J.; Wong, R.; Charest, A. The multifaceted roles of the receptor tyrosine kinase ROS in development and cancer. Biochim. Biophys. Acta 2009, 1795, 37-52. [CrossRef] [PubMed]

10. Charest, A.; Lane, K.; McMahon, K.; Park, J.; Preisinger, E.; Conroy, H.; Housman, D. Fusion of FIG to the receptor tyrosine kinase ROS in a glioblastoma with an interstitial del(6)(q21q21). Genes Chromosom. Cancer 2003, 37, 58-71. [CrossRef]

11. Rikova, K.; Guo, A.; Zeng, Q.; Possemato, A.; Yu, J.; Haack, H.; Nardone, J.; Lee, K.; Reeves, C.; Li, Y.; et al. Global Survey of Phosphotyrosine Signaling Identifies Oncogenic Kinases in Lung Cancer. Cell 2007, 131, 1190-1203. [CrossRef]

12. Dagogo-Jack, I.; Rooney, M.; Nagy, R.J.; Lin, J.J.; Chin, E.; Ferris, L.A.; Ackil, J.; Lennerz, J.K.; Lanman, R.B.; Gainor, J.F.; et al. Molecular Analysis of Plasma From Patients With ROS1-Positive NSCLC. J. Thorac. Oncol. 2019, 14, 816-824. [CrossRef]

13. Zhang, Q.; Wu, C.; Ding, W.; Zhang, Z.; Qiu, X.; Mu, D.; Zhang, H.; Xi, Y.; Zhou, J.; Ma, L.; et al. Prevalence of ROS1 fusion in Chinese patients with non-small cell lung cancer. Thorac. Cancer 2018, 10, 47-53. [CrossRef]

14. Davies, K.D.; Doebele, R.C. Molecular Pathways: ROS1 Fusion Proteins in Cancer. Clin. Cancer Res. 2013, 19, 4040-4045. [CrossRef] [PubMed] 
15. Charest, A.; Wilker, E.W.; McLaughlin, M.E.; Lane, K.; Gowda, R.; Coven, S.; McMahon, K.; Kovach, S.; Feng, Y.; Yaffe, M.B.; et al. ROS fusion tyrosine kinase activates a $\mathrm{SH} 2$ domain-containing phosphatase-2/phosphatidylinositol 3-kinase/mammalian target of rapamycin signaling axis to form glio-blastoma in mice. Cancer Res. 2006, 66, 7473-7481. [CrossRef] [PubMed]

16. Jun, H.J.; Johnson, H.; Bronson, R.T.; De Feraudy, S.; White, F.; Charest, A. The Oncogenic Lung Cancer Fusion Kinase CD74-ROS Activates a Novel Invasiveness Pathway through E-Syt1 Phosphorylation. Cancer Res. 2012, 72, 3764-3774. [CrossRef] [PubMed]

17. Bergethon, K.; Shaw, A.T.; Ou, S.-H.I.; Katayama, R.; Lovly, C.M.; McDonald, N.T.; Massion, P.P.; Siwak-Tapp, C.; Gonzalez, A.; Fang, R.; et al. ROS1 Rearrangements Define a Unique Molecular Class of Lung Cancers. J. Clin. Oncol. 2012, 30, 863-870. [CrossRef] [PubMed]

18. Cai, W.; Li, X.; Su, C.; Fan, L.; Zheng, L.; Fei, K.; Zhou, C.; Manegold, C.; Schmid-Bindert, G. ROS1 fusions in Chinese patients with non-small-cell lung cancer. Ann. Oncol. 2013, 24, 1822-1827. [CrossRef]

19. Fu, S.; Liang, Y.; Lin, Y.-B.; Wang, F.; Huang, M.-Y.; Zhang, Z.-C.; Wang, J.; Cen, W.-J.; Shao, J.-Y. The Frequency and Clinical Implication of ROS1 and RET Rearrangements in Resected Stage IIIA-N2 Non-Small Cell Lung Cancer Patients. PLoS ONE 2015, 10, e0124354. [CrossRef]

20. Zhu, Q.; Zhan, P.; Zhang, X.; Lv, T.; Song, Y. Clinicopathologic characteristics of patients with ROS1 fusion gene in non-small cell lung cancer: A meta-analysis. Transl. Lung Cancer Res. 2015, 4, 300-309. [CrossRef]

21. Drilon, A.; Jenkins, C.; Iyer, S.; Schoenfeld, A.; Keddy, C.; Davare, M.A. ROS1-dependent cancers-Biology, diagnostics and therapeutics. Nat. Rev. Clin. Oncol. 2021, 18, 35-55. [CrossRef]

22. Patil, T.; Smith, D.E.; Bunn, P.A.; Aisner, D.L.; Le, A.T.; Hancock, M.; Purcell, W.T.; Bowles, D.W.; Camidge, D.R.; Doebele, R.C. The Incidence of Brain Metastases in Stage IV ROS1-Rearranged Non-Small Cell Lung Cancer and Rate of Central Nervous System Progression on Crizotinib. J. Thorac. Oncol. 2018, 13, 1717-1726. [CrossRef]

23. Park, S.; Ahn, B.-C.; Lim, S.W.; Sun, J.-M.; Kim, H.R.; Hong, M.H.; Lee, S.-H.; Ahn, J.S.; Park, K.; La Choi, Y.; et al. Characteristics and Outcome of ROS1-Positive Non-Small Cell Lung Cancer Patients in Routine Clinical Practice. J. Thorac. Oncol. 2018, 13, 1373-1382. [CrossRef]

24. Warth, A.; Muley, T.; Dienemann, H.; Goeppert, B.; Stenzinger, A.; A Schnabel, P.; Schirmacher, P.; Penzel, R.; Weichert, W. ROS1expression and translocations in non-small-cell lung cancer: clinicopathological analysis of 1478 cases. Histopathology 2014, 65, 187-194. [CrossRef]

25. Park, E.; Choi, Y.-L.; Ahn, M.-J.; Han, J. Histopathologic characteristics of advanced-stage ROS1-rearranged non-small cell lung cancers. Pathol. Res. Pract. 2019, 215, 152441. [CrossRef] [PubMed]

26. Ju, L.; Han, M.; Su, J.; Wu, C.; Dong, Z. A lung squamous carcinoma patient with ROS1 rearrangement sensitive to crizotinib. Cancer Chemother. Pharmacol. 2018, 82, 561-564. [CrossRef] [PubMed]

27. Yoshida, A.; Kohno, T.; Tsuta, K.; Wakai, S.; Arai, Y.; Shimada, Y.; Asamura, H.; Furuta, K.; Shibata, T.; Tsuda, H. ROS1-rearranged lung cancer: A clinicopathologic and molecular study of 15 surgical cases. Am. J. Surg. Pathol. 2013, 37, 554-562. [CrossRef] [PubMed]

28. Digumarthy, S.R.; Mendoza, D.P.; Lin, J.J.; Chen, T.; Rooney, M.M.; Chin, E.; Sequist, L.V.; Lennerz, J.K.; Gainor, J.F.; Shaw, A.T. Computed Tomography Imaging Features and Distribution of Metastases in ROS1-rearranged Non-Small-cell Lung Cancer. Clin. Lung Cancer 2020, 21, 153-159.e3. [CrossRef] [PubMed]

29. Otoshi, R.; Sekine, A.; Okudela, K.; Katano, T.; Asaoka, M.; Ikeda, S.; Baba, T.; Komatsu, S.; Hagiwara, E.; Ogura, T. Miliary lung metastases from ROS1-rearranged lung adenocarcinoma: A case report. Mol. Clin. Oncol. 2020, 13, 80-82. [CrossRef] [PubMed]

30. Zhu, V.W.; Zhao, J.J.; Gao, Y.; Syn, N.L.; Zhang, S.S.; Ou, S.-H.I.; Bauer, K.A.; Nagasaka, M. Thromboembolism in ALK+ and ROS1+ NSCLC patients: A systematic review and meta-analysis. Lung Cancer 2021, 157, 147-155. [CrossRef]

31. Shah, A.T.; Bernardo, R.J.; Berry, G.J.; Kudelko, K.; Wakelee, H.A. Two Cases of Pulmonary Tumor Thrombotic Microangi-opathy Associated with ROS1-Rearranged Non-Small-Cell Lung Cancer. Clin. Lung Cancer 2021, 22, e153-e156. [CrossRef]

32. Woodford, R.; Lu, M.; Beydoun, N.; Cooper, W.; Liu, Q.; Lynch, J.; Kasherman, L. Disseminated intravascular coagulation complicating diagnosis of ROS1 -mutant non-small cell lung cancer: A case report and literature review. Thorac. Cancer 2021, 12, 2400-2403. [CrossRef]

33. Wahrenbrock, M.; Borsig, L.; Le, D.; Varki, N.; Varki, A. Selectin-mucin interactions as a probable molecular explanation for the association of Trousseau syndrome with mucinous adenocarcinomas. J. Clin. Investig. 2003, 112, 853-862. [CrossRef]

34. Cui, M.; Han, Y.; Li, P.; Zhang, J.; Ou, Q.; Tong, X.; Zhao, R.; Dong, N.; Wu, X.; Li, W.; et al. Molecular and clinicopathological characteristics of ROS1-rearranged non-small-cell lung cancers identified by next-generation sequencing. Mol. Oncol. 2020, 14, 2787-2795. [CrossRef] [PubMed]

35. Huang, R.S.P.; Haberberger, J.; Sokol, E.; Schrock, A.B.; Danziger, N.; Madison, R.; Trabucco, S.; Jin, D.; Pavlick, D.; Ramanan, V.; et al. Clinicopathologic, genomic and protein expression characterization of 356 ROS1 fusion driven solid tumors cases. Int. J. Cancer 2021, 148, 1778-1788. [CrossRef] [PubMed]

36. Li, Z.; Shen, L.; Ding, D.; Huang, J.; Zhang, J.; Chen, Z.; Lu, S. Efficacy of Crizotinib among Different Types of ROS1 Fusion Partners in Patients with ROS1-Rearranged Non-Small Cell Lung Cancer. J. Thorac. Oncol. 2018, 13, 987-995. [CrossRef] [PubMed]

37. Takeuchi, K.; Soda, M.; Togashi, Y.; Suzuki, R.; Sakata, S.; Hatano, S.; Asaka, R.; Hamanaka, W.; Ninomiya, H.; Uehara, H.; et al. RET, ROS1 and ALK fusions in lung cancer. Nat. Med. 2012, 18, 378-381. [CrossRef] [PubMed] 
38. Huang, R.S.; Gottberg-Williams, A.; Vang, P.; Yang, S.; Britt, N.; Kaur, J.; Haberberger, J.; Danziger, N.; Owens, C.; Beckloff, S.E.; et al. Correlating ROS1 Protein Expression With ROS1 Fusions, Amplifications, and Mutations. JTO Clin. Res. Rep. 2021, 2. [CrossRef] [PubMed]

39. Xu, S.; Wang, W.; Xu, C.; Li, X.; Ye, J.; Zhu, Y.; Ge, T. ROS1-ADGRG6: a case report of a novel ROS1 oncogenic fusion variant in lung adenocarcinoma and the response to crizotinib. BMC Cancer 2019, 19, 1-4. [CrossRef]

40. Huang, R.S.P.; Smith, D.; Le, C.H.; Liu, W.-W.; Ordinario, E.; Manohar, C.; Lee, M.; Rajamani, J.; Truong, H.; Li, J.; et al. Correlation of ROS1 Immunohistochemistry With ROS1 Fusion Status Determined by Fluorescence In Situ Hybridization. Arch. Pathol. Lab. Med. 2019, 144, 735-741. [CrossRef]

41. Zheng, J.; Cao, H.; Li, Y.; Rao, C.; Zhang, T.; Luo, J.; Lv, D.; Zhu, Y.; Zhou, J.; Zhou, J. Effectiveness and prognostic factors of first-line crizotinib treatment in patients with ROS1-rearranged non-small cell lung cancer: A multicenter retrospective study. Lung Cancer 2020, 147, 130-136. [CrossRef]

42. Zhu, Y.-C.; Zhou, Y.-F.; Wang, W.-X.; Xu, C.-W.; Zhuang, W.; Du, K.-Q.; Chen, G. CEP72-ROS1: A novel ROS1 oncogenic fusion variant in lung adenocarcinoma identified by next-generation sequencing. Thorac. Cancer 2018, 9, 652-655. [CrossRef]

43. Lin, J.J.; Shaw, A.T. Recent Advances in Targeting ROS1 in Lung Cancer. J. Thorac. Oncol. 2017, 12, 1611-1625. [CrossRef]

44. Lan, S.; Li, H.; Liu, Y.; Xu, J.; Huang, Z.; Yan, S.; Zhang, Q.; Cheng, Y. A Novel ROS1-FBXL17 Fusion Co-Existing with CD74-ROS1 Fusion May Improve Sensitivity to Crizotinib and Prolong Progression-Free Survival of Patients with Lung Adenocarcinoma. OncoTargets Ther. 2020, 13, 11499-11504. [CrossRef] [PubMed]

45. Shu, Y.; Li, H.; Shang, H.; Chen, J.; Su, X.; Le, W.; Lei, Y.; Tao, L.; Zou, C.; Wu, W. Identification of a Novel MPRIP-ROS1 Fusion and Clinical Efficacy of Crizotinib in an Advanced Lung Adenocarcinoma Patient: A Case Report. OncoTargets Ther. 2020, 13, 10387-10391. [CrossRef] [PubMed]

46. Landi, L.; Chiari, R.; Tiseo, M.; D'Incà, F.; Dazzi, C.; Chella, A.; Delmonte, A.; Bonanno, L.; Giannarelli, D.; Cortinovis, D.L.; et al. Crizotinib in MET-Deregulated or ROS1-Rearranged Pretreated Non-Small Cell Lung Cancer (METROS): A Phase II, Prospective, Multicenter, Two-Arms Trial. Clin. Cancer Res. 2019, 25, 7312-7319. [CrossRef] [PubMed]

47. Zhang, Y.; Yu, M.; Yuan, M.; Chen, R.; Huang, M.-J. Identification of a Novel RBPMS-ROS1 Fusion in an Adolescent Patient With Microsatellite-instable Advanced Lung Adenocarcinoma Sensitive to Crizotinib: A Case Report. Clin. Lung Cancer 2019, 21, e78-e83. [CrossRef] [PubMed]

48. Wiesweg, M.; Eberhardt, W.E.; Reis, H.; Ting, S.; Savvidou, N.; Skiba, C.; Herold, T.; Christoph, D.C.; Meiler, J.; Worm, K.; et al. High Prevalence of Concomitant Oncogene Mutations in Prospectively Identified Patients with ROS1-Positive Metastatic Lung Cancer. J. Thorac. Oncol. 2016, 12, 54-64. [CrossRef] [PubMed]

49. Lin, J.J.; Ritterhouse, L.L.; Ali, S.M.; Bailey, M.; Schrock, A.B.; Gainor, J.F.; Ferris, L.A.; Mino-Kenudson, M.; Miller, V.A.; Iafrate, A.J.; et al. ROS1 Fusions Rarely Overlap with Other Oncogenic Drivers in Non-Small Cell Lung Cancer. J. Thorac. Oncol. 2017, 12, 872-877. [CrossRef]

50. Uguen, A.; Schick, U.; Quéré, G. A Rare Case of ROS1 and ALK Double Rearranged Non-Small Cell Lung Cancer. J. Thorac. Oncol. 2017, 12, e71-e72. [CrossRef]

51. Xu, C.-W.; Zhu, Y.-C.; Ye, X.-Q.; Yin, M.-X.; Zhang, J.-X.; Du, K.-Q.; Zhang, Z.-H.; Hu, J. Lung cancer with concurrent EGFR mutation and ROS1 rearrangement: a case report and review of the literature. OncoTargets Ther. 2016, 9, 4301-4305. [CrossRef]

52. Lambros, L.; Guibourg, B.; Uguen, A. ROS1-rearranged Non-Small Cell Lung Cancers With Concomitant Oncogenic Driver Alterations: About Some Rare Therapeutic Dilemmas. Clin. Lung Cancer 2018, 19, e73-e74. [CrossRef]

53. Song, Z.; Zheng, Y.; Wang, X.; Su, H.; Zhang, Y.; Song, Y. ALK and ROS1 rearrangements, coexistence and treatment in epi-dermal growth factor receptor-wild type lung adenocarcinoma: A multicenter study of 732 cases. J. Thorac. Dis. 2017, 9, 3919-3926. [CrossRef]

54. Tang, Z.; Zhang, J.; Lu, X.; Wang, W.; Chen, H.; Robinson, M.K.; Cheng, J.; Tang, G.; Medeiros, L.J. Coexistent genetic alterations involving ALK, RET, ROS1 or MET in 15 cases of lung adenocarcinoma. Mod. Pathol. 2017, 31, 307-312. [CrossRef] [PubMed]

55. Rihawi, K.; Cinausero, M.; Fiorentino, M.; Salvagni, S.; Brocchi, S.; Ardizzoni, A. Co-alteration of c-Met and ROS1 in Advanced NSCLC: ROS1 Wins. J. Thorac. Oncol. 2018, 13, e41-e43. [CrossRef] [PubMed]

56. Zeng, L.; Li, Y.; Xiao, L.; Xiong, Y.; Liu, L.; Jiang, W.; Heng, J.; Qu, J.; Yang, N.; Zhang, Y. Crizotinib presented with promising efficacy but for concomitant mutation in next-generation sequencing-identified ROS1-rearranged non-small-cell lung cancer. OncoTargets Ther. 2018, 11, 6937-6945. [CrossRef] [PubMed]

57. Lindeman, N.I.; Cagle, P.T.; Aisner, D.L.; Arcila, M.E.; Beasley, M.B.; Bernicker, E.H.; Colasacco, C.; Dacic, S.; Hirsch, F.R.; Kerr, K.; et al. Updated Molecular Testing Guideline for the Selection of Lung Cancer Patients for Treatment With Targeted Tyrosine Kinase Inhibitors: Guideline From the College of American Pathologists, the International Association for the Study of Lung Cancer, and the Association for Molecular Pathology. Arch. Pathol. Lab. Med. 2018, 142, 321-346. [CrossRef]

58. Mosele, F.; Remon, J.; Mateo, J.; Westphalen, C.; Barlesi, F.; Lolkema, M.; Normanno, N.; Scarpa, A.; Robson, M.; MericBernstam, F.; et al. Recommendations for the use of next-generation sequencing (NGS) for patients with metastatic cancers: a report from the ESMO Precision Medicine Working Group. Ann. Oncol. 2020, 31, 1491-1505. [CrossRef]

59. Makarem, M.; Ezeife, D.A.; Smith, A.C.; Li, J.J.N.; Law, J.H.; Tsao, M.-S.; Leighl, N.B. Reflex ROS1 IHC Screening with FISH Confirmation for Advanced Non-Small Cell Lung Cancer-A Cost-Efficient Strategy in a Public Healthcare System. Curr. Oncol. 2021, 28, 3268-3279. [CrossRef] 
60. Wang, W.; Cheng, G.; Zhang, G.; Song, Z. Evaluation of a new diagnostic immunohistochemistry approach for ROS1 rearrangement in non-small cell lung cancer. Lung Cancer 2020, 146, 224-229. [CrossRef]

61. Bubendorf, L.; Büttner, R.; Al-Dayel, F.; Dietel, M.; Elmberger, G.; Kerr, K.; López-Ríos, F.; Marchetti, A.; Öz, B.; Pauwels, P.; et al. Testing for ROS1 in non-small cell lung cancer: a review with recommendations. Virchows Arch. 2016, 469, 489-503. [CrossRef]

62. Hofman, V.; Rouquette, I.; Long-Mira, E.; Piton, N.; Chamorey, E.; Heeke, S.; Vignaud, J.M.; Yguel, C.; Mazières, J.; Lepage, A.-L.; et al. Multicenter Evaluation of a Novel ROS1 Immunohistochemistry Assay (SP384) for Detection of ROS1 Rearrangements in a Large Cohort of Lung Adenocarcinoma Patients. J. Thorac. Oncol. 2019, 14, 1204-1212. [CrossRef]

63. Fielder, T.; Butler, J.; Tierney, G.; Holmes, M.; Lam, K.Y.; Satgunaseelan, L.; Colebatch, A.J.; Mahar, A.; Gupta, R.; O’Toole, S.; et al. ROS1 rearrangements in lung adenocarcinomas are defined by diffuse strong immunohistochemical expression of ROS1. Pathology 2021, 23, S0031-3025(21)00477-3. [CrossRef]

64. Cheung, C.C.; Smith, A.C.; Albadine, R.; Bigras, G.; Bojarski, A.; Couture, C.; Cutz, J.-C.; Huang, W.-Y.; Ionescu, D.; Itani, D.; et al. Canadian ROS proto-oncogene 1 study (CROS) for multi-institutional implementation of ROS1 testing in non-small cell lung cancer. Lung Cancer 2021, 160, 127-135. [CrossRef] [PubMed]

65. Sholl, L.M.; Weremowicz, S.; Gray, S.W.; Wong, K.-K.; Chirieac, L.R.; Lindeman, N.I.; Hornick, J.L. Combined use of ALK immuno-histochemistry and FISH for optimal detection of ALK-rearranged lung adenocarcinomas. J. Thorac. Oncol. 2013, 8, 322-328. [CrossRef] [PubMed]

66. Wilcock, D.M.; Schmidt, R.L.; Furtado, L.V.; Matynia, A.P.; Deftereos, G.; Sirohi, D. Histologic and Molecular Characterization of Non-Small Cell Lung Carcinoma With Discordant ROS1 Immunohistochemistry and Fluorescence In Situ Hybridization. Appl. Immunohistochem. Mol. Morphol. 2021, 30, 19-26. [CrossRef] [PubMed]

67. Zito Marino, F.; Rossi, G.; Cozzolino, I.; Montella, M.; Micheli, M.; Bogina, G.; Munari, E.; Brunelli, M.; Franco, R. Multiplex fluorescence in situ hybridisation to detect anaplastic lymphoma kinase and ROS proto-oncogene 1 receptor tyrosine kinase rearrangements in lung cancer cy-tological samples. J. Clin. Pathol. 2020, 73, 96-101. [CrossRef] [PubMed]

68. Ginestet, F.; Lambros, L.; Le Flahec, G.; Marcorelles, P.; Uguen, A. Evaluation of a Dual ALK/ROS1 Fluorescent In Situ Hybridization Test in Non-Small-cell Lung Cancer. Clin. Lung Cancer 2018, 19, e647-e653. [CrossRef] [PubMed]

69. Clavé, S.; Rodon, N.; Pijuan, L.; Díaz, O.; Lorenzo, M.; Rocha, P.; Taus, Á.; Blanco, R.; Bosch-Barrera, J.; Reguart, N.; et al. Nextgeneration Sequencing for ALK and ROS1 Re-arrangement Detection in Patients with Non-Small-Cell Lung Cancer: Implications of FISH-positive Patterns. Clin. Lung Cancer 2019, 20, e421-e429. [CrossRef] [PubMed]

70. Kim, S.-W.; Do, S.-I.; NA, K. External Validation of ALK and ROS1 Fusions Detected Using an Oncomine Comprehensive Assay. Anticancer Res. 2021, 41, 4609-4617. [CrossRef]

71. Suehara, Y.; Arcila, M.; Wang, L.; Hasanovic, A.; Ang, D.; Ito, T.; Kimura, Y.; Drilon, A.; Guha, U.; Rusch, V.; et al. Identification of KIF5B-RET and GOPC-ROS1 fusions in lung adenocarcinomas through a comprehensive mRNA-based screen for tyrosine kinase fusions. Clin. Cancer Res. 2012, 18, 6599-6608. [CrossRef]

72. Capizzi, E.; Dall'Olio, F.G.; Gruppioni, E.; Sperandi, F.; Altimari, A.; Giunchi, F.; Fiorentino, M.; Ardizzoni, A. Clinical significance of ROS1 5' deletions in non-small cell lung cancer. Lung Cancer 2019, 135, 88-91. [CrossRef]

73. Wong, S.Q.; Li, J.; Tan, A.Y.-C.; Vedururu, R.; Pang, J.-M.B.; Do, H.; Ellul, J.; Doig, K.; Bell, A.; MacArthur, G.A.; et al. Sequence artefacts in a prospective series of forma-lin-fixed tumours tested for mutations in hotspot regions by massively parallel sequencing. BMC Med. Genom. 2014, 7, 23. [CrossRef]

74. Shan, L.; Lian, F.; Guo, L.; Qiu, T.; Ling, Y.; Ying, J.; Lin, D. Detection of ROS1 Gene Rearrangement in Lung Adenocarcinoma: Comparison of IHC, FISH and Real-Time RT-PCR. PLoS ONE 2015, 10, e0120422. [CrossRef] [PubMed]

75. Davies, K.D.; Le, A.T.; Sheren, J.; Nijmeh, H.; Gowan, K.; Jones, K.L.; Varella-Garcia, M.; Aisner, D.L.; Doebele, R.C. Comparison of Molecular Testing Modalities for Detection of ROS1 Rearrangements in a Cohort of Positive Patient Samples. J. Thorac. Oncol. 2018, 13, 1474-1482. [CrossRef] [PubMed]

76. Benayed, R.; Offin, M.; Mullaney, K.; Sukhadia, P.; Rios, K.; Desmeules, P.; Ptashkin, R.; Won, H.; Chang, J.; Halpenny, D.; et al. High Yield of RNA Sequencing for Targetable Kinase Fusions in Lung Adenocarcinomas with No Mitogenic Driver Alteration Detected by DNA Sequencing and Low Tumor Mutation Burden. Clin. Cancer Res. 2019, 25, 4712-4722. [CrossRef] [PubMed]

77. Shaw, A.; Riely, G.; Bang, Y.-J.; Kim, D.-W.; Camidge, D.; Solomon, B.; Varella-Garcia, M.; Iafrate, A.; Shapiro, G.; Usari, T.; et al. Crizotinib in ROS1-rearranged advanced non-small-cell lung cancer (NSCLC): Updated results, including overall survival, from PROFILE 1001. Ann. Oncol. 2019, 30, 1121-1126. [CrossRef]

78. Mazières, J.; Zalcman, G.; Crinò, L.; Biondani, P.; Barlesi, F.; Filleron, T.; Dingemans, A.M.; Léna, H.; Monnet, I.; Rothschild, S.I.; et al. Crizotinib therapy for advanced lung adeno-carcinoma and a ROS1 rearrangement: Results from the EUROS1 cohort. J. Clin. Oncol. 2015, 33, 992-999. [CrossRef]

79. Shen, L.; Qiang, T.; Li, Z.; Ding, D.; Yu, Y.; Lu, S. First-line crizotinib versus platinum-pemetrexed chemotherapy in patients with advanced ROS1-rearranged non-small-cell lung cancer. Cancer Med. 2020, 9, 3310-3318. [CrossRef]

80. Moro-Sibilot, D.; Cozic, N.; Pérol, M.; Mazières, J.; Otto, J.; Souquet, P.; Bahleda, R.; Wislez, M.; Zalcman, G.; Guibert, S.; et al. Crizotinib in c-MET- or ROS1-positive NSCLC: Results of the AcSé phase II trial. Ann. Oncol. 2019, 30, 1985-1991. [CrossRef]

81. Michels, S.; Massutí, B.; Schildhaus, H.-U.; Franklin, J.; Sebastian, M.; Felip, E.; Grohé, C.; Rodriguez-Abreu, D.; Abdulla, D.S.; Bischoff, H.; et al. Safety and Efficacy of Crizotinib in Patients With Advanced or Metastatic ROS1-Rearranged Lung Cancer (EUCROSS): A European Phase II Clinical Trial. J. Thorac. Oncol. 2019, 14, 1266-1276. [CrossRef] 
82. Wu, Y.-L.; Yang, J.C.-H.; Kim, D.-W.; Lu, S.; Zhou, J.; Seto, T.; Yang, J.-J.; Yamamoto, N.; Ahn, M.-J.; Takahashi, T.; et al. Phase II Study of Crizotinib in East Asian Patients With ROS1-Positive Advanced Non-Small-Cell Lung Cancer. J. Clin. Oncol. 2018, 36, 1405-1411. [CrossRef]

83. He, Y.; Sheng, W.; Hu, W.; Lin, J.; Liu, J.; Yu, B.; Mao, X.; Zhang, L.; Huang, J.; Wang, G. Different Types of ROS1 Fusion Partners Yield Comparable Efficacy to Crizotinib. Oncol. Res. Featur. Preclin. Clin. Cancer Ther. 2019, 27, 901-910. [CrossRef]

84. Zhang, Y.; Zhang, X.; Zhang, R.; Xu, Q.; Yang, H.; Lizaso, A.; Xu, C.; Liu, J.; Wang, W.; Ou, S.I.; et al. Clinical and molecular factors that impact the efficacy of first-line crizotinib in ROS1-rearranged non-small-cell lung cancer: A large multicenter retrospective study. BMC Med. 2021, 19, 206. [CrossRef] [PubMed]

85. Ardini, E.; Menichincheri, M.; Banfi, P.; Bosotti, R.; De Ponti, C.; Pulci, R.; Ballinari, D.; Ciomei, M.; Texido, G.; Degrassi, A.; et al. Entrectinib, a Pan-TRK, ROS1, and ALK Inhibitor with Activity in Multiple Molecularly Defined Cancer Indications. Mol. Cancer Ther. 2016, 15, 628-639. [CrossRef] [PubMed]

86. Rolfo, C.; Ruiz, R.; Giovannetti, E.; Gil-Bazo, I.; Russo, A.; Passiglia, F.; Giallombardo, M.; Peeters, M.; Raez, L. Entrectinib: A potent new TRK, ROS1, and ALK inhibitor. Expert Opin. Investig. Drugs 2015, 24, 1493-1500. [CrossRef] [PubMed]

87. Drilon, A.; Siena, S.; Ou, S.-H.I.; Patel, M.; Ahn, M.J.; Lee, J.; Bauer, T.M.; Farago, A.F.; Wheler, J.J.; Liu, S.V.; et al. Safety and Antitumor Activity of the Multitargeted Pan-TRK, ROS1, and ALK Inhibitor Entrectinib: Combined Results from Two Phase I Trials (ALKA-372-001 and STARTRK-1). Cancer Discov. 2017, 7, 400-409. [CrossRef] [PubMed]

88. Drilon, A.; Siena, S.; Dziadziuszko, R.; Barlesi, F.; Krebs, M.G.; Shaw, A.T.; de Braud, F.; Rolfo, C.; Ahn, M.-J.; Wolf, J.; et al. Entrectinib in ROS1 fusion-positive non-small-cell lung cancer: Integrated analysis of three phase 1-2 trials. Lancet Oncol. 2019, 21, 261-270. [CrossRef]

89. Dziadziuszko, R.; Krebs, M.G.; De Braud, F.; Siena, S.; Drilon, A.; Doebele, R.C.; Patel, M.R.; Cho, B.C.; Liu, S.V.; Ahn, M.-J.; et al. Updated Integrated Analysis of the Efficacy and Safety of Entrectinib in Locally Advanced or Metastatic ROS1 Fusion-Positive Non-Small-Cell Lung Cancer. J. Clin. Oncol. 2021, 39, 1253-1263. [CrossRef]

90. Paz-Ares, L.; Barlesi, F.; Siena, S.; Ahn, M.-J.; Drilon, A.; Conley, A.; Rolfo, C.; Wolf, J.; Seto, T.; Doebele, R.; et al. Patient-reported outcomes from STARTRK-2: A global phase II basket study of entrectinib for ROS1 fusion-positive non-small-cell lung cancer and NTRK fusion-positive solid tu-mours. ESMO Open 2021, 6, 100113. [CrossRef]

91. Ardini, E.; Siena, S. Entrectinib approval by EMA reinforces options for ROS1 and tumour agnostic NTRK targeted cancer therapies. ESMO Open 2020, 5, e000867. [CrossRef]

92. Shaw, A.T.; Felip, E.; Bauer, T.M.; Besse, B.; Navarro, A.; Postel-Vinay, S.; Gainor, J.F.; Johnson, M.; Dietrich, J.; James, L.P.; et al. Lorlatinib in non-small-cell lung cancer with ALK or ROS1 rearrangement: an international, multicentre, open-label, single-arm first-in-man phase 1 trial. Lancet Oncol. 2017, 18, 1590-1599. [CrossRef]

93. Solomon, B.J.; Besse, B.; Bauer, T.M.; Felip, E.; Soo, R.A.; Camidge, D.R.; Chiari, R.; Bearz, A.; Lin, C.-C.; Gadgeel, S.M.; et al. Lorlatinib in patients with ALK-positive non-small-cell lung cancer: results from a global phase 2 study. Lancet Oncol. 2018, 19, 1654-1667. [CrossRef]

94. Shaw, A.T.; Solomon, B.J.; Chiari, R.; Riely, G.J.; Besse, B.; A Soo, R.; Kao, S.; Lin, C.-C.; Bauer, T.M.; Clancy, J.S.; et al. Lorlatinib in advanced ROS1-positive non-small-cell lung cancer: a multicentre, open-label, single-arm, phase 1-2 trial. Lancet Oncol. 2019, 20, 1691-1701. [CrossRef]

95. Chen, J.; Ruiz-Garcia, A.; James, L.P.; Peltz, G.; Thurm, H.; Clancy, J.; Hibma, J. Lorlatinib Exposure-Response Analyses for Safety and Efficacy in a Phase I/II Trial to Support Benefit-Risk Assessment in Non-Small Cell Lung Cancer. Clin. Pharmacol. Ther. 2021, 110, 1273-1281. [CrossRef] [PubMed]

96. Peters, S.; Shaw, A.T.; Besse, B.; Felip, E.; Solomon, B.J.; Soo, R.A.; Bearz, A.; Gadgeel, S.M.; Lin, C.-C.; Kao, S.; et al. Impact of lorlatinib on patient-reported outcomes in patients with advanced ALK-positive or ROS1-positive non-small cell lung cancer. Lung Cancer 2020, 144, 10-19. [CrossRef]

97. Wu, X.; Wang, Y.; Wan, S.; Zhang, J. Investigation on the binding mechanism of loratinib with the c-ros oncogene 1 (ROS1) receptor tyrosine kinase via molecular dynamics simulation and binding free energy calculations. J. Biomol. Struct. Dyn. 2017, 36, 3106-3113. [CrossRef] [PubMed]

98. Facchinetti, F.; Levy, A.; Ammari, S.; Naltet, C.; Lavaud, P.; Aldea, M.; Vasseur, D.; Planchard, D.; Besse, B. Meningeal “Lazarus Response" to Lorlatinib in a ROS1-Positive NSCLC Patient Progressing to Entrectinib. Cancer Manag. Res. 2021, 13, $2805-2810$. [CrossRef]

99. Shaw, A.T.; Kim, T.M.; Crinò, L.; Gridelli, C.; Kiura, K.; Liu, G.; Novello, S.; Bearz, A.; Gautschi, O.; Mok, T.; et al. Ceritinib versus chemotherapy in patients with ALK-rearranged non-small-cell lung cancer previously given chemotherapy and crizotinib (ASCEND-5): a randomised, controlled, open-label, phase 3 trial. Lancet Oncol. 2017, 18, 874-886. [CrossRef]

100. Drilon, A.; Somwar, R.; Wagner, J.P.; Vellore, N.A.; Eide, C.A.; Zabriskie, M.S.; Arcila, M.E.; Hechtman, J.F.; Wang, L.; Smith, R.S.; et al. A Novel Crizotinib-Resistant Sol-vent-Front Mutation Responsive to Cabozantinib Therapy in a Patient with ROS1Rearranged Lung Cancer. Clin. Cancer Res. 2016, 22, 2351-2358. [CrossRef]

101. Sun, T.Y.; Niu, X.; Chakraborty, A.; Neal, J.W.; Wakelee, H.A. Lengthy Progression-Free Survival and Intracranial Activity of Cabozantinib in Patients with Crizotinib and Ceritinib-Resistant ROS1-Positive Non-Small Cell Lung Cancer. J. Thorac. Oncol. 2018, 14, e21-e24. [CrossRef]

102. Katayama, R.; Kobayashi, Y.; Friboulet, L.; Lockerman, E.L.; Koike, S.; Shaw, A.T.; Engelman, J.A.; Fujita, N. Cabozantinib Overcomes Crizotinib Resistance in ROS1 Fusion-Positive Cancer. Clin. Cancer Res. 2014, 21, 166-174. [CrossRef] 
103. Zhang, S.; Anjum, R.; Squillace, R.; Nadworny, S.; Zhou, T.; Keats, J.; Ning, Y.; Wardwell, S.D.; Miller, D.; Song, Y.; et al. The Potent ALK Inhibitor Brigatinib (AP26113) Overcomes Mechanisms of Resistance to First- and Second-Generation ALK Inhibitors in Preclinical Models. Clin. Cancer Res. 2016, 22, 5527-5538. [CrossRef]

104. Dudnik, E.; the Israel Lung Cancer Group; Agbarya, A.; Grinberg, R.; Cyjon, A.; Bar, J.; Moskovitz, M.; Peled, N. Clinical activity of brigatinib in ROS1-rearranged non-small cell lung cancer. Clin. Transl. Oncol. 2020, 22, 2303-2311. [CrossRef] [PubMed]

105. Hegde, A.; Hong, D.S.; Behrang, A.; Ali, S.M.; Juckett, L.; Meric-Bernstam, F.; Subbiah, V. Activity of Brigatinib in Crizotinib and Ceritinib-Resistant ROS1- Rearranged Non-Small-Cell Lung Cancer. JCO Precis. Oncol. 2019, 3, 1-6. [CrossRef] [PubMed]

106. Camidge, D.R.; Kim, D.-W.; Tiseo, M.; Langer, C.J.; Ahn, M.-J.; Shaw, A.T.; Huber, R.M.; Hochmair, M.J.; Lee, D.H.; Bazhenova, L.A.; et al. Exploratory Analysis of Brigatinib Activity in Patients With Anaplastic Lymphoma Kinase-Positive Non-Small-Cell Lung Cancer and Brain Metastases in Two Clinical Trials. J. Clin. Oncol. 2018, 36, 2693-2701. [CrossRef]

107. Yun, M.R.; Kim, D.H.; Kim, S.-Y.; Joo, H.-S.; Lee, Y.W.; Choi, H.M.; Park, C.W.; Heo, S.G.; Na Kang, H.; Lee, S.S.; et al. Repotrectinib Exhibits Potent Antitumor Activity in Treatment-Naïve and Solvent-Front-Mutant ROS1-Rearranged Non-Small Cell Lung Cancer. Clin. Cancer Res. 2020, 26, 3287-3295. [CrossRef]

108. Katayama, R.; Gong, B.; Togashi, N.; Miyamoto, M.; Kiga, M.; Iwasaki, S.; Kamai, Y.; Tominaga, Y.; Takeda, Y.; Kagoshima, Y.; et al. The new-generation selective ROS1/NTRK inhibitor DS-6051b overcomes crizotinib resistant ROS1-G2032R mutation in preclinical models. Nat. Commun. 2019, 10, 3604. [CrossRef] [PubMed]

109. Papadopoulos, K.P.; Borazanci, E.; Shaw, A.T.; Katayama, R.; Shimizu, Y.; Zhu, V.W.; Sun, T.Y.; Wakelee, H.A.; Madison, R.; Schrock, A.B.; et al. U.S. Phase I First-in-human Study of Taletrectinib (DS-6051b/AB-106), a ROS1/TRK Inhibitor, in Patients with Advanced Solid Tumors. Clin. Cancer Res. 2020, 26, 4785-4794. [CrossRef] [PubMed]

110. Horn, L.; Infante, J.R.; Reckamp, K.L.; Blumenschein, G.R.; Leal, T.A.; Waqar, S.N.; Gitlitz, B.J.; Sanborn, R.E.; Whisenant, J.G.; Du, L.; et al. Ensartinib (X-396) in ALK-Positive Non-Small Cell Lung Cancer: Results from a First-in-Human Phase I/II, Multicenter Study. Clin. Cancer Res. 2018, 24, 2771-2779. [CrossRef]

111. Ai, X.; Wang, Q.; Cheng, Y.; Liu, X.; Cao, L.; Chen, J.; Dong, X.; Zhou, J.; Fan, Y.; Huang, C.; et al. Safety but Limited Efficacy of Ensartinib in ROS1-Positive NSCLC: A Single-Arm, Multicenter Phase 2 Study. J. Thorac. Oncol. 2021, 16, 1959-1963. [CrossRef]

112. Liang, Y.; Wakelee, H.A.; Neal, J.W. Relationship of Driver Oncogenes to Long-Term Pemetrexed Response in Non-Small-Cell Lung Cancer. Clin. Lung Cancer 2014, 16, 366-373. [CrossRef]

113. Watanabe, H.; Ichihara, E.; Kayatani, H.; Makimoto, G.; Ninomiya, K.; Nishii, K.; Higo, H.; Ando, C.; Okawa, S.; Nakasuka, T.; et al. VEGFR2 blockade augments the effects of tyrosine kinase inhibitors by inhibiting angiogenesis and oncogenic signaling in oncogene-driven non-small-cell lung cancers. Cancer Sci. 2021, 112, 1853-1864. [CrossRef]

114. Saito, H.; Fukuhara, T.; Furuya, N.; Watanabe, K.; Sugawara, S.; Iwasawa, S.; Tsunezuka, Y.; Yamaguchi, O.; Okada, M.; Yoshimori, K.; et al. Erlotinib plus bevacizumab versus erlotinib alone in patients with EGFR-positive advanced non-squamous non-small-cell lung cancer (NEJ026): Interim analysis of an open-label, randomised, multicentre, phase 3 trial. Lancet Oncol. 2019, 20, 625-635. [CrossRef]

115. Choudhury, N.J.; Schneider, J.L.; Patil, T.; Zhu, V.W.; Goldman, D.A.; Yang, S.-R.; Falcon, C.J.; Do, A.; Nie, Y.; Plodkowski, A.J.; et al. Response to Immune Checkpoint Inhibition as Monotherapy or in Combination With Chemotherapy in Metastatic ROS1Rearranged Lung Cancers. JTO Clin. Res. Rep. 2021, 2, 100187. [CrossRef] [PubMed]

116. Mazieres, J.; Drilon, A.; Lusque, A.B.; Mhanna, L.; Cortot, A.; Mezquita, L.; Thai, A.A.; Mascaux, C.; Couraud, S.; Veillon, R.; et al. Immune checkpoint inhibitors for patients with advanced lung cancer and oncogenic driver alterations: results from the IMMUNOTARGET registry. Ann. Oncol. 2019, 30, 1321-1328. [CrossRef] [PubMed]

117. Guisier, F.; Dubos-Arvis, C.; Viñas, F.; Doubre, H.; Ricordel, C.; Ropert, S.J.; Janicot, H.; Bernardi, M.; Fournel, P.; Lamy, R.; et al. Efficacy and Safety of Anti-PD-1 Immuno-therapy in Patients With Advanced NSCLC With BRAF, HER2, or MET Mutations or RET Translocation: GFPC 01-2018. J. Thorac. Oncol. 2020, 15, 628-636. [CrossRef] [PubMed]

118. McCoach, C.E.; Le, A.T.; Gowan, K.; Jones, K.; Schubert, L.; Doak, A.; Estrada-Bernal, A.; Davies, K.D.; Merrick, D.T.; Bunn, P.A.; et al. Resistance Mechanisms to Targeted Therapies in ROS1+ and ALK+ Non-small Cell Lung Cancer. Clin. Cancer Res. 2018, 24, 3334-3347. [CrossRef] [PubMed]

119. Lin, J.J.; Choudhury, N.J.; Yoda, S.; Zhu, V.W.; Johnson, T.W.; Sakhtemani, R.; Dagogo-Jack, I.; Digumarthy, S.R.; Lee, C.; Do, A.; et al. Spectrum of Mechanisms of Resistance to Crizotinib and Lorlatinib in ROS1 Fusion-Positive Lung Cancer. Clin. Cancer Res. 2021, 27, 2899-2909. [CrossRef]

120. Awad, M.M.; Katayama, R.; McTigue, M.; Liu, W.; Deng, Y.-L.; Brooun, A.; Friboulet, L.; Huang, D.; Falk, M.D.; Timofeevski, S.; et al. Acquired Resistance to Crizotinib from a Mutation in CD74-ROS1. N. Engl. J. Med. 2013, 368, 2395-2401. [CrossRef]

121. Gou, W.; Zhou, X.; Liu, Z.; Wang, L.; Shen, J.; Xu, X.; Li, Z.; Zhai, X.; Zuo, D.; Wu, Y. CD74-ROS1 G2032R mutation transcriptionally up-regulates Twist1 in non-small cell lung cancer cells leading to increased migration, invasion, and resistance to crizotinib. Cancer Lett. 2018, 422, 19-28. [CrossRef]

122. Song, A.; Kim, T.M.; Kim, D.-W.; Kim, S.; Keam, B.; Lee, S.-H.; Heo, D.S. Molecular Changes Associated with Acquired Resistance to Crizotinib in ROS1-Rearranged Non-Small Cell Lung Cancer. Clin. Cancer Res. 2015, 21, 2379-2387. [CrossRef]

123. Facchinetti, F.; Loriot, Y.; Cassin-Kuo, M.-S.; Mahjoubi, L.; Lacroix, L.; Planchard, D.; Besse, B.; Farace, F.; Auger, N.; Remon, J.; et al. Crizotinib-Resistant ROS1 Mutations Reveal a Predictive Kinase Inhibitor Sensitivity Model for ROS1- and ALK-Rearranged Lung Cancers. Clin. Cancer Res. 2016, 22, 5983-5991. [CrossRef] 
124. Roys, A.; Chang, X.; Liu, Y.; Xu, X.; Wu, Y.; Zuo, D. Resistance mechanisms and potent-targeted therapies of ROS1-positive lung cancer. Cancer Chemother. Pharmacol. 2019, 84, 679-688. [CrossRef] [PubMed]

125. Li, Z.; Lin, Y.; Chi, X.; Xu, M.; Wang, H. Appearance of an ALK mutation conferring resistance to crizotinib in non-small cell lung cancer harboring oncogenic ROS1 fusion. Lung Cancer 2021, 153, 174-175. [CrossRef] [PubMed]

126. Ren, S.; Huang, S.; Ye, X.; Feng, L.; Lu, Y.; Zhou, C.; Zhao, J.; He, T.; Wang, J.; Li, B. Crizotinib resistance conferred by BRAF V600E mutation in non-small cell lung cancer harboring an oncogenic ROS1 fusion. Cancer Treat. Res. Commun. 2021, $27,100377$. [CrossRef] [PubMed]

127. Wang, Y.; Chen, Z.; Han, X.; Li, J.; Guo, H.; Shi, J. Acquired MET D1228N Mutations Mediate Crizotinib Resistance in Lung Adenocarcinoma with ROS1 Fusion: A Case Report. Oncologist 2020, 26, 178-181. [CrossRef] [PubMed]

128. Yang, J.; Zhou, P.; Yu, M.; Zhang, Y. Case Report: High-Level MET Amplification as a Resistance Mechanism of ROS1-Tyrosine Kinase Inhibitors in ROS1-Rearranged Non-Small Cell Lung Cancer. Front. Oncol. 2021, 11. [CrossRef] [PubMed]

129. Lin, J.J.; Langenbucher, A.; Gupta, P.; Yoda, S.; Fetter, I.J.; Rooney, M.; Do, A.; Kem, M.; Chang, K.P.; Oh, A.Y.; et al. Small cell transformation of ROS1 fusion-positive lung cancer resistant to ROS1 inhibition. npj Precis. Oncol. 2020, 4, 1-8. [CrossRef] [PubMed]

130. Fares, A.F.; Lok, B.H.; Zhang, T.; Cabanero, M.; Lau, S.C.M.; Stockley, T.; Patel, D.; Bradbury, P.A.; Sacher, A.; Yasufuku, K.; et al. ALK-rearranged lung adenocarcinoma trans-formation into high-grade large cell neuroendocrine carcinoma: Clinical and molecular description of two cases. Lung Cancer 2020, 146, 350-354. [CrossRef] [PubMed]

131. Marcoux, N.; Gettinger, S.N.; O’Kane, G.; Arbour, K.C.; Neal, J.W.; Husain, H.; Evans, T.L.; Brahmer, J.R.; Muzikansky, A.; Bonomi, P.D.; et al. EGFR-Mutant Adenocarcinomas That Transform to Small-Cell Lung Cancer and Other Neuroendocrine Carcinomas: Clinical Outcomes. J. Clin. Oncol. 2019, 37, 278-285. [CrossRef]

132. Planchard, D.; Popat, S.; Kerr, K.; Novello, S.; Smit, E.F.; Faivre-Finn, C.; Mok, T.S.; Reck, M.; Van Schil, P.E.; Hellmann, M.D.; et al. Metastatic non-small cell lung cancer: ESMO Clinical Practice Guidelines for diagnosis, treatment and follow-up. Ann. Oncol. 2018, 29 (Suppl. 4), iv192-iv237. [CrossRef]

133. Almquist, D.; Ernani, V. The Road Less Traveled: A Guide to Metastatic ROS1-Rearranged Non-Small-Cell Lung Cancer. JCO Oncol. Pract. 2021, 17, 7-14. [CrossRef] 